\title{
The Social Politics of Fatherhood in Spain and France: a Comparative Analysis of Parental Leave and Shared Residence
}

Anna Escobedo

Université de Barcelone

Lluís Flaquer

Université autonome de Barcelone

Lara Navarro-Varas

Université autonome de Barcelone

\section{RÉSUMÉ}

Les politiques sociales de la paternité en France et en Espagne : une analyse comparée du congé parental et de la résidence partagée

L'article présente une analyse comparative de l'évolution des politiques relatives aux congés paternels et à la garde conjointe en Espagne et en France dans la dernière décennie. Ces deux mesures sont toutes deux largement reconnues comme instruments importants de la promotion de nouveaux styles de paternité et par conséquent d'une plus grande égalité entre hommes et femmes dans l'Union européenne. Alors que la rhétorique du choix a été développée dans les deux pays en matière d'emploi de la mère et de garde d'enfants, avec de meilleurs résultats en France qu'en Espagne, il reste à voir dans quelle mesure la possibilité de choix sera aussi ouverte aux pères.

Mots-clés: Paternité. Famille. Politique sociale comparée. Congé parental. Garde conjointe.

Anna Escobedo

Department of Sociology

and Organizational Analysis

Faculty of Economics and Business

Universidad de Barcelona

Diagonal 690

08034 Barcelona

Espagne

anna.escobedo@ub.edu

\section{Lluís Flaquer}

Sociology Department, Building B

Universidad Autonòma de Barcelona

Campus of Bellaterra -

Plaça Nord, edifici MRA, planta 2 08193 Bellaterra

Espagne

lluis.flaquer@uab.cat

\author{
Lara Navarro-Varas \\ The Institute of Regional and Metropolitan \\ Studies of Barcelona (IERMB) \\ Universidad Autonòma de Barcelona \\ Campus of Bellaterra - \\ Plaça Nord, edifici MRA, planta 2 \\ 08193 Bellaterra \\ Espagne \\ lara.navarro@uab.cat
}

While the social construction of motherhood together with the cultural and institutional construction of the relationship between working parents and the welfare state has for long focused most research attention, in recent years the inquiry into the social politics of fatherhood has been gaining a more prominent status in the research agenda [Hobson and Morgan, 2002]. Whereas for many years the role of fathers as economic providers has been taken for granted, only in recent times their contribution to families as potential carers is being considered and developed as a significant research theme. Even if the promotion of the adult worker family model form has become central to contemporary family policies, there is still a clear ambivalence around the measures applied to achieve equal opportunities for mothers and fathers. In general mothers have better conditions for paid parental leave or to adapt flexible working schedules. Although it is true that fathers' caring responsibilities are increasingly recognised in most countries, the shift from the male breadwinner family towards a new adult worker model requires a fundamental reorganisation of welfare states. Only promoting men's participation in unpaid care at a similar level as women's, particularly in childcare and upbringing, will genuinely improve gender equality. In this context, it is important to examine the extent to which European welfare states are increasingly supporting as well as enforcing the right of children to receive care from both parents by assessing innovative policy developments in so far as they can contribute to the construction of a new fatherhood.

The purpose of this article is to provide a comparative analysis of policy developments on leaves for fathers and joint custody in Spain and France in the last decade. These two types of measures have been selected in the extent to which they are both widely recognised as main instruments to promote new fathering styles and consequently more gender equality in 
the European Union. The introduction of a father quota and of joint legal custody as the norm after divorce in many countries following the lead of the Nordic nations is supplying very rich experiences to comparative research [Björnberg, 2006; Duvander and Jans, 2008]. It is also expected that these new social practices as well as institutional arrangements will bring about an enhancement of the children's well being. The comparison between Spain and France appears relevant because although both neighbouring countries exhibit very different path dependency patterns of welfare state development, in fact their provisions for shared residence and paternal leave are not quite dissimilar. $^{1}$

\section{- General comparative overview}

The comparison of family policies toward new fatherhood in France and Spain is problematic because these two countries have long exhibited to a great extent different patterns of social structure and paths of development. Before proceeding to describe specific trends and measures regarding new fatherhood policies it may be useful to provide a general overview of family policies in France and Spain so that it is possible to understand the significance of new developments and place them in their proper context.

While France has undoubtedly been one of the European leaders in the historical modernization process, Spain is clearly a latecomer as far as economic and political development is concerned and it may be still considered as an outlier in many respects. However, since the democratic transition and in particular during the last decade Spain has been catching up very quickly. To give only one single example in order to illustrate the exponential growth of parameters influencing family policies in Spain in recent years, while from 1998 to 2009 economic activity rates of women aged 25 to 54 years have increased by 17.2 percentage points, in France they have only risen by 5.2 points (the EU-25 average being 6.6 points) ${ }^{2}$.

Despite this dramatic change in women's labour market participation, in a European perspective Spain is still lagging behind in its development of family policy. The contrast between the significance of family policy in France and Spain may be easily visualized by looking at different rates of social expenditure in family and children in these two countries. Whereas Spain only devotes to family and children $1.50 \%$ of GDP (358 $€$ per inhabitant), the resources spent by France in this area are much larger: $2.47 \%$ of GDP and $749 €$ per inhabitant ${ }^{3}$. These great disparities can be explained by different timings of development and path dependence patterns. While in Spain family policy has been the Cinderella of social policies since the democratic transition, in France its prominence is undisputed and it has gathered a wide political consensus over a long period of time [Valiente, 1997; Commaille and Martin, 1998]. This brief outline about different patterns of development and the visibility of family policies in both countries may help understanding how, in general, France has been much ahead than Spain in the occurrence of most debates and in the introduction of new measures.

\section{- The development of paternal leave in Spain and France}

Parental leave policies emerged in the seventies as a mechanism to protect family formation and the upbringing of children in dual earner family societies. Progressively more gender-neutral family-related leaves have been in development in Europe as part of the emerging gender, care and work arrangements in society. Leave arrangements for working parents and informal careers in European policy have become a regulatory mechanism of the changing relationships between individuals in families, the labour market and the state.

Parental leave schemes are regulated forms of absence from normal work, connected to social protection, in order to facilitate parenting and the care of children. They provide time, economic support and job protection to parents as individual as well as family entitlements related to a newborn or a small child. Leave schemes for working parents are mainly: maternity leave (congé de maternité); paternity leave (congé de paternitê); parental leave or childcare leave (congé parental d'éducation); and leave to care for a sick child. A few countries have fused these previous categories into a single modernized parental leave scheme with unified earnings-related conditions.

Parental leave is presently contributing to the shaping of new forms of both motherhood and fatherhood - a more planned, negotiated and reflexive parenthood. It involves the social definition and legitimacy of 
protected but also limited periods of time devoted to upbringing. These periods are defined and socially constructed in different ways for women and men. Nevertheless, the new trends in leave policies suggest the development of more gender neutral and flexible pools of care leave entitlements, together with public support for the development of early childhood education and care service sectors [Deven and Moss, 1999; Kamerman and Moss, 2009]. This gives scope for new individual choices and a more reflexive way to deal with parenthood and informal family-based care both for men and women.

O'Brien discusses how parental leave has the potential to boost the father's emotional investment and connection with infants. She suggests the possibility of a new polarization for infants: the risk of being born into either a "parental leave-rich" or "parental leavepoor" household or country [O'Brien, 2009]. Within this perspective, fathers risk more than mothers through a loss of contact with their children after divorce, as a result of lower previous investments in direct physical parental care.

Parental leave is a social policy mechanism conceived to counteract economic effects, protecting maternal attachment to employment, while promoting male involvement in child raising. Effective parental leave systems can alleviate these types of social risks, provided that they guarantee job security, economic stability, gender sharing, and the individualization of parental care bonds. Male groups and movements have particularly supported the father's individual entitlements to leave as a basis for his bonding with children, and caring involvement since birth, to promote caring routines to prevent or alleviate the effects of conjugal breakdown later on, particularly to preserve the contacts between fathers and children [Nordic Council of Ministers, 1995]. Researchers have evidenced that parental leave policies actively promoting a caring fatherhood contribute to modify the distribution of the roles and the tasks between mothers and fathers since the transition to parenthood in different Northern European countries in a more egalitarian direction with longstanding effects [Rostgaard, 2002; Lammi-Taskula, 2006; O’Brien, Brandth and Kvande, 2007; Moss, 2008].

Parental leave, defined as an earning-related entitlement encompassing fathers was introduced in Sweden in 1974. In the 1990s, parental leave spreads over Europe with a growing attention on gender sharing. Against the fact that fathers rarely use family defined entitlements, Norway introduced in 1993 the individualization of some of the periods of parental leave for the father (the father's quotas), Sweden followed this mechanism in 1995, and Iceland introduced in 2000 a $3+3+3$ parental leave system, where three months are for the mother, three for the father and three months can be used as wished by the family. The three cases nearly automatically succeeded in raising, in the same proportion as the father's quota, the father's share of leave entitlements. As an approach to the father's share of total leave arrangements for working parents, in 2007 the percentage of total paid leave days used by fathers amounted to $31 \%$ in Iceland, $22 \%$ in Sweden, $11 \%$ in Norway, $6 \%$ in Denmark and Finland [Haataja, 2009].

Following the expansion of comparative policy methods, in the 2000s most EU countries have revised and closely followed up their policies of parental leave. Fathers non-transferable parental leave entitlements are spreading across countries either on a "use-it or loseit" or conceptualized as an extra well paid leave bonus for the family (e.g. in Finland, Germany or more recently in Portugal). Also paternity leave is being extended in time, and as paternity leave is not currently regulated at EU level, in 2010 the European Parliament proposed to regulate two weeks of fully paid paternity leave, in the framework of the discussion of a new maternity leave directive (amendment 125 of the EP's position adopted on 20/10/2010). French ethnographic research has emphasized the interest of paternity leave to support a more active presence of fathers at birth. Fathers can then innovate to some extent the matrifocal practices in maternity hospitals and healthcare policies, and experience different starting patterns of fathering [Truc, 2006].

In 2010, twenty of the EU Member States have statutory paternity leave, ranging from 2 to 90 working days, with compensation ranging from no payment to full payment. Take-up rates of paternity leave are relatively high, with more than two thirds of fathers generally taking up such provisions where they are available [EPEC-COWI, forthcoming].

France developed in 1985 a parental leave scheme (congé parental d'éducation, within the Labour Code) connected to a flat rate benefit, initially addressed to large families, later extended to two-child parents in 1994 and finally to single-child parents in 2004 within a broader reform of the French child related allowances. The scheme is now available as a family entitlement either on a full-time or part-time basis, for six months following the end of maternity leave, in case 
of a first child, or otherwise until the child is 3 . The benefit (complément de libre choix d'activité, CLCA, paid by CNAF) ranges from $560.40 €$ per month on a fulltime basis in 2011 (approximately half of the minimum wage in France), to $322.24 €$ on part-time basis, up to $80 \%$ of normal working time in the company. It is often supplemented by other family allowances. The benefit is largely used by mothers: by one out of eight of families with a first child, and by more than half of the families with two or more children, the youngest under 3 year-olds (41\% use it part-time, more than half of them also receive a childcare benefit: le complément de libre choix du mode de garde). Fathers represented $3.7 \%$ of the recipients in 2009, $1.4 \%$ of recipients were partners using it part-time [Nicolas, 2010].

Various researches have documented to what extend the full-time benefit is largely used by both mothers and fathers with lower education and wages, reinforcing gender and social inequalities [Fagnani, 2009; Berger, Chauffaut et al., 2006]. Recipient fathers more easily have a more qualified couple with higher earnings or belong to atypical family configurations [Anxo, Delander and Månsson, 2006; Boyer and Renouard, 2004].

In the 2000's the father's use of the French leave system was more clearly introduced in the agenda. In 2002 paternity leave was extended from three working days to two weeks. While the extended 11 days were paid by the Social Security, the first 3 days remained paid by the employer. Two-thirds of eligible French fathers take paternity leave according to the most recent data available.

The gender equality debate has mostly focused in France between promoters of good quality publicly funded childcare facilities and promoters of the option to take care of small children at home, resulting in what has been considered a parental choice orientated leave policy model [Wall and Escobedo, 2009]. As a result France has both a high coverage of mostly publiclyfunded childcare services for small children (around $40 \%$ of children under 3 years old, Eurostat EU-SILC), and despite gender neutral discourses, a parental leave system is mostly orientated to mothers, particularly to low paid mothers, for whom benefits are a feasible alternative to low wages. However the low share of paternal use of the French leaves is relevant since it points to more diverse family configurations and parenting styles [Chevalier, 2006].

In Spain the leave system has pivoted between 1980 and 2007 on a well paid maternity leave and a pool of unpaid gender neutrally defined parental leave available until the child was 3 , or working time reductions until children were 6 , the stronger policy focus clearly being on extending early education to pre-school children. A short leave policy model linked to traditional patterns of extended family care was assumed in Spain, with a strong emphasis on female labour market integration, and little attention to leave policies.

Leave policy turned into an issue from 2000 onwards, when the concept of reconciliation of work and family became popular in the Spanish policy agenda, following European directives, the European Employment Strategy and Gender Equality Plans while maternal employment was on the rise. Various autonomous communities (the Spanish state is decentralized in 17 regions) started to introduce flat rate benefits (lower and more restrictive than in France, ranging from one third to four fifths in some cases of the minimum wage, which in Spain is $641 €$ in 2011) to stimulate the take-up of unpaid parental leaves or the use of working time reductions. In 2007 central state policies moved the focus of the leave policies towards paternity leave and towards very flexible voluntary and reversible working time reductions. From the perspective of early childhood and care policies the focus has always remained on expanding early childhood education and care (ECEC). As a result the Spanish ECEC coverage is currently very similar to the French (around $40 \%$ of the under 3's and nearly $100 \%$ of children 3 years old up to compulsory school age, which is 6 in both countries), but with a lower share (around $12 \%$ ) of the under 3 in publicly-funded facilities [MEC, 2011].

In 2007 a new paternity leave scheme was introduced, very similar to the French scheme, in the framework of a Gender Equality Law (Ley Orgánica 3/2007, para la Igualdad efectiva de mujeres $y$ hombres). It was the first time that fathers received an individualized entitlement paid by the social insurance system, the previous two days of birth leave for fathers being paid by employers. The 2007 legislation included a commitment to a four-week paternity leave, expected to be implemented from $1^{\text {rst }}$ January 2011, but the measure has been postponed in the context of public budget cutbacks as a result of the financial crisis.

The length of paternity leave is currently of fifteen days, paid one hundred percent of earnings, by the Social Security Fund with the same ceiling as maternity leave, except for the first two days that continue to be paid by employers or by self-employed in the 
private sector. The entitlement is gender neutral so as to encompass same-sex couples. The rate of Spanish eligible fathers taking paternity leave is slowly but steadily growing from $54 \%$ in 2008 to $58 \%$ in $2010^{4}$.

At the same time, unpaid working time reductions have been extended and made more flexible for families: from one eighth to one half of working time until a child is 8 (or 12 in the public sector) or to care for a dependent relative ${ }^{5}$.

In 2008, 37,771 people started some period of parental leave. This corresponds to $7 \%$ of the births in that year, but only $2.5 \%$ of children under three. Fathers made up 4 percent of users [Statistical Yearbook of the Ministry of Labour]. Research has estimated that between 1989 and $200596 \%$ of users have been mothers, with a median length of leaves of 184 days and $4 \%$ fathers with a median length of leaves of 172 days; $36 \%$ of fathers and $26 \%$ of mothers used unpaid parental leave for less than three months. $11 \%$ of user mothers and $25 \%$ of user fathers did not return to the same company, which means that in these cases the use of parental leave is connected to a change in employment status [Escobedo, Navarro and Flaquer, 2008].

Research results suggest that the Spanish parental leave scheme increases gender and social inequalities, as it reinforces gender role specialization and only supports the reconciliation of work and family life among workers with a stable position in the labour market [Lapuerta, Baizán and González, 2010].

Based on data on complementary measures in the Catalan public sector produced for years 2003-2006, it was possible to find out that fathers made a high use of specific parental leave arrangements, on part-time or full-time basis, that were well paid on an earningsrelated basis, worked as individual non-transferable entitlements, highly protected, in favorable workplace cultures. Under these conditions the observed female use of partial leave measures has also been noticeably high. Part-time leave arrangements are shown to be in that case a type of good quality, voluntary and reversible working time arrangement.

First France in 2002 and then Spain in 2007 have developed paternity leave schemes in a very similar way. Parental leave remains in both countries not much widely used by fathers, as in Spain is unpaid and not much used by mothers either, and in France is paid at a flat rate (about half of the minimum wage) and much more used by mothers. While the rhetoric of choice is being developed in both countries, in practice choice seems rather restricted to some groups of mothers, and is higher in France than in Spain. Both fertility and female employment rates are higher in France than Spain (2 versus 1,4 children per woman, and $77 \%$ of female employment versus $64 \%$ in 2009 in the 25-54 age group, with around on quarter of women on parttime mostly voluntary in France and unwished in Spain [EC, 2010]). However non-affordable schemes cannot be considered in practice as a real entitlement, particularly for fathers who are taking on breadwinner roles in societal contexts with pronounced gender pay and employment gaps.

Both France and Spain have a strong focus on services for small children, but a specific discourse and policy measures are still lacking in order to promote male participation in early childhood education and care services or broader social services, despite the fact that it has been identified as a positive resource to enhance new ways for fatherhood in other countries [Escobedo, 2008; Cameron and Moss, 2007]. Likewise both countries exhibited similar levels - around $40 \%-$ of children under 3 years old in childcare formal services. Whilst in both countries political parties and women's groups are much more orientated to childcare, in France we find a dominant discourse involving job creation and incentivizing a diversity of schemes in contrast to Spain where childcare for children under 3 is mainly integrated in the educational system but with about half of the provision remaining in fact outside educational regulation. This duality in the Spanish childcare sector is due to decentralized policies and a complex regulatory developments in the $0-3$ that have allowed the expansion of alternative and cheaper childcare services, without public support and with quality problems [Flaquer and Escobedo, 2009]. For children older than 3 years, the French and Spanish educational system guarantee universal coverage, but school hours and terms do not always easily fit working parents schedules.

In Spain from 2007 onwards leave policies are perceived as a means to promote men's take-up of care work and to increase their participation in the upbringing of children. Following the Nordic and in particular the Icelandic experience, feminist elites are currently proposing to develop a leave system with equal non transferable paid entitlements both men and women as a strategy to further male participation in the care of children and to offset the stigmatization of women in the labour market. Men's movements in favour of new 
masculinities, paternities or demanding joint custody after divorce seem to support this approach.

\section{- Joint custody and shared residence in Spain and France}

In this section we assume that the increase in the adoption of joint custody and shared residence after divorce could be a good opportunity to develop new fathering practices. We hope that a comparison of the Spanish and French experiences in this respect can shed light on this issue. The last available Eurostat data for crude divorce rates show very similar figures for both countries: 2.1 divorces per 1,000 populations.

Attitudes towards joint custody have changed in the last two decades, especially as a result of the entry into force of the UN Convention on the Rights of the Child, and in many countries it has become the preferred arrangement being widely accepted as reflecting the best interests of children of divorced parents [Kurki-Suonio, 2000; Ryrstedt, 2003]. Traditional visiting patterns and guidelines are, for the majority of children, outdated, unnecessarily rigid, and restrictive, and fail in both the short and long term to address their best interests [Hunt and Roberts, 2004; Emery et al., 2005; Kelly, 2007]. Sole custody most often consists of the allocation of the care of children to the mother, while the father takes exclusive (or a great part of) responsibility for economic maintenance. Considering that this kind of arrangement stems from the logic of the male breadwinner family system, it does not seem to be very adequate in societies where most mothers are doing paid work and an increasingly number of fathers are wishing to take an active part in the care of their children.

There are various forms of joint custody and an important distinction should be made between joint legal and physical custody. Joint legal custody means that both parents share the right and the obligation of making major decisions about their child's upbringing (e.g. about schooling, religion, and health care). On the other hand, joint physical custody means that the child spends a significant amount of time with each parent and his/her daily care is divided between both parents to a considerable extent [Kurki-Suonio, 2000; Halla, 2009]. While joint physical custody generally involves legal custody, one cannot make the reverse implication. Shared residence or alternating residence are expressions that may be taken as synonyms of joint physical custody, but each of them conveys peculiar connotations [Granet, 2008].

Non-residence with a child is the single greatest predictor of low father or mother involvement. Shared parenting across households is likely to be more prevalent in countries where shared residence agreements are more widespread following divorce or separation [Flouri, 2005; The Fatherhood Institute, 2010]. Considering that research findings in Sweden indicate that fathers' parental leave is associated with more contact between non resident separated fathers and their children [Duvander and Jans, 2008], we may wonder whether in Spain and in France there is a certain correlation between the generosity of parental leave entitlements and the prevalence of shared parenting arrangements after divorce.

Joint custody (custodia compartida) was introduced in Spain by the 2005 Divorce Act, a most liberal and no-fault divorce law that provided for a simplification of proceedings involving direct access to divorce without going through any prior formal separation. The definition of joint custody given by the 2005 Divorce Act is purely formal. Parents may agree (or the judge may decide on behalf of children) that parental authority will be exercised totally or partially by one of spouses. Joint custody may be granted by the judge if demanded by both parents, but also exceptionally if requested by only one of them. In the latter case the decision should only be made in the best interest of the children after a favourable report from the public official in charge of the protection of children (fiscal) (Art. 92. 8). Joint custody will never be granted if the judge suspects the existence of gender-based violence.

The law does not specify whether joint custody must be interpreted only legally or both legally and physically. No guidelines are given concerning who is liable to pay for child maintenance or what residential arrangements should be agreed in keeping with joint custody.

In France shared residence (résidence en alternance or résidence alternée) of children from separated parents is legally recognised from the 2002-305 Act (4 March 2002) on parental authority (article 372-2-9 of the French Civil code). The law enables the judge to fix alternating residence if requested by both parents (article 373-2-9); in case of disagreement between father and mother, the judge may still order it provisionally for a certain period of time. However, even if there is a consensus between both parents, the judge is free not 
to grant alternating residence if children's interest is not fully secured [Kesteman, 2007; Brunet, Kertudo et Malsan, 2008]. Alternating residence is more than simple joint physical custody, since it not only means that the child spends significant amounts of time with both parents, but supposes equal amounts in an alternating manner, even if it does not systematically imply strict shared physical custody. Alternating residence can be seen as a sort of 'dual residence' [Granet, 2008].

While sociological research on shared residence in France exhibits a long-standing tradition [Neyrand, 1994], in Spain it is just in the bud. In more than half of divorces in Spain and France minor children are involved (Spain: 53.3 \%, 2009 ; France : 57 \%, 2007). In Spain joint custody is ordered by courts in about one out of ten cases of divorces involving minor children $(9.6 \%)$, but only in $6 \%$ of cases of divorces involving children both parents are due to pay maintenance [INE, 2010]. Data reported for France show the $15 \%$ of children whose parents divorced in 2007 used to live in alternating residence [Neyrand, 1994; Kesteman, 2007], while $8 \%$ lived with their fathers and the rest with their mothers. While in Spain the incidence of joint custody seems to be stable over time, French data show an increase of alternating residence during the 2000s: $11.5 \%$ in 2003 and $13.5 \%$ in 2006. The more contentious is the divorce, the less frequent is alternating residence. While the part of shared residence in divorces by mutual consent is $21.5 \%$, it is only $11 \%$ in accepted divorces and $4 \%$ in divorces by fault [Chaussebourg, Carrasco et Lermenier, 2009]. Although data for both countries are not strictly comparable, it can be suggested that the prevalence of shared residence in France is not only much higher than in Spain but it is clearly on the increase.

What are the main factors underlying the different prevalence of joint custody in France and Spain? A number of reasons may be adduced. In the first place, the well-established tradition of divorce in France in contrast to Spain, where it has only been in force for three decades, may contribute to explain the higher proclivity of the French to adopt new measures regarding divorce. Secondly, although the participation of women in the labour market has dramatically risen in Spain in recent years, middle-aged French women have still higher activity rates than the Spanish ones $(83.6 \%$ versus $76.7 \%),{ }^{6}$ and this, together with persistent unemployment rates for women in Spain, probably explains the existence of less gender-balanced couples in this country.
Thirdly, and this is surely the most critical factor, both the late development of the welfare state and the low profile of family policy in Spain are associated with more adverse consequences of divorce for women and this is probably reinforcing traditional choices [Flaquer, 2008; Flaquer and Garriga, 2009]. Our thesis is that differing outcomes between France and Spain are not so much due to differences in the legal regulation of divorce but in the social conditions and opportunities provided by the characteristics of the productive and welfare regimes. In fact, the comparison between the legislation on divorce in France and Spain shows many similarities. While it is true that access to divorce has been simplified to a great extent in the 2005 Spanish law, a number of other familialistic provisions have been left in place such as the allocation of the family dwelling to the family unit in which children live as a rule of thumb and the obligation to pay maintenance to the custodian parent (most generally the mother) after the age majority of the child. We also find similar provisions in the French law, but their long-term consequences are not the same. It is important to bear in mind that in Spain there is not only a high prevalence of home ownership (about $85 \%$ in Spain versus $63 \%$ in France), but that also youth transitions are much longer than in France as young people tend to leave home during their late twenties [Jurado, 2001; Cabré and Módenes, 2004]. The interplay of both features contributes to a long perpetuation of gender imbalance situations considering that the split of owner-occupied dwellings is generally postponed until all children have left home.

This is the backdrop to the debate on shared residence in Spain. Joint custody is presently a controversial issue and a lively discussion in the Spanish media has been opposing groups and associations for and against it. In the state civil law no legal presumption exists over the attribution of custody by the judge so that joint custody is only to be granted if both parents agree it. However, under certain circumstances joint custody can be exceptionally decreed in case of disagreement between father and mother. However, the legislators of some autonomous communities have recently envisaged the establishment of joint custody as the preferred arrangement even if parents fail to agree over the matter. Thus, the parliament of Aragon has passed a Law of Equality in Family Relations after Divorce (2010) that institutes joint custody as the preferential custody arrangement. Likewise, the new Catalan Civil Code (2010) has also established joint 
custody as the standard although non-mandatory arrangement. Other Northern regions are following suit and the reform of state civil law is under study.

The drafting of new legislation has been accompanied by pressure exerted by different fathers' associations, feminist groups and political parties in pursuit of their ideological stances and in defence of their interests. Unfortunately little evidence-based research has been used to give support to different views. One gets the impression that maintaining or changing the status quo to the proposers' own advantage are more important drives than trying to achieve gender equity or enhancing child well-being.

We assume that in Spain the debate on shared residence has less to do with the promotion of shared parenting and a new fatherhood than with the defence of gender-based interests. Lines of cleavage among activist groups or lobbies over the reform of divorce laws tend often to reproduce the preservation of the (or the fight against) status quo in terms of economic interests between ex-spouses. The radicalization of the debate between associations of separated fathers and mothers has basically to do with the gender imbalance sustained by current legislation that, while it overprotects separated mothers in a social context of gender inequality, it imposes a heavy and long-standing financial burden on separated fathers. Once again a wide gap appears between gender egalitarian ideals expressed by the majority of the Spanish population and legal, social as well as economic constraints acting as barriers preventing citizens from putting them into practice [Xavier Roigé, this volume]. The comparison with France is relevant here because it shows that a similar civil legislation in a context of a different welfare regime produces a friendlier attitude towards joint custody.

Parental leave remains in both countries used by a low proportion of atypical fathers while the fully paid paternity leave scheme is widely used. Non-affordable schemes cannot be considered in practice as a real entitlement, particularly for fathers who are taking on breadwinner roles in societal contexts with pronounced gender pay and employment gaps. However the incipient use of paternal leave indicates the emergence of new fathering styles and more diverse household configurations. While the rhetoric of choice has been developed in both countries in relation to maternal employment and childcare, until now with better results in France than in Spain, it remains to be seen to what extent choice will also be extended to fathers. In both countries atypical family arrangements and part-time parental combinations may account for future developments.

We are fully aware that we should not take for granted an equation between the adoption of joint custody and the promotion of a new fatherhood. In certain cases enforcing by courts joint custody and shared residence could result in more conflict. At any rate, much more research is needed in order to ascertain whether new fatherhood is really promoted by the generalization of joint custody by enquiring into the particular circumstances and requirements that are conducive to the most beneficial results for both parents and children.

The rise of joint custody is promoting new male demands as well as a more widespread use of leave and of formal or informal work-family arrangements. A higher paternal share of parental and care leave is unambiguously highlighted as a virtuous genderequality development in European policies. Therefore we suggest to do more in-depth research on how divorced and lone fathers use work-family arrangements (parental leave, leave to take care of sick children, flexible time arrangements at work, or homeworking), especially focusing on how they develop specific strategies and use profiles, in different labour market contexts as well as in various production and welfare regime frameworks.

\section{Notes}

1. The research presented in this article has been conducted in the context of the research programme ANRPATERNITE, projet ANR-08-JCJC-0057-01.
2. Eurostat data.

3. Eurostat, data for year 2008.

4. Own calculation based on Social Security and INE data; birth data is provisional for 2010 .

5. For detailed and updated explanations of leave schemes available in France, Spain as well other countries, see the Annual reviews of the Leave Policies and Research Expert Network available from 2005 onwards [Moss and KoCOURKOVÀ, 2010] at www.leavenetwork. org.

6. Eurostat data for 2009. Middle aged women stands for females aged 25-54 years. 


\section{Bibliography}

AnXo Dominique, Lennart Delander and Jonas MÅnsSOn, 2006, "Les déterminants socio-économiques de l'utilisation des congés parentaux par les pères. Une analyse comparative entre la France et la Suède ", Recherches et Prévisions, 84: 19-33.

Berger Emmanuel, Delphine Chauffaut, Christine Olm et Marie-Odile SimON, 2006, "Les bénéficiaires du Complément de libre choix d'activité: une diversité de profils ", Etudes et Résultats, 510, DREES: 1-7.

BjÖRnBERG Ulla, 2006, "Paying for the Costs of Children in Eight North European Countries: Ambivalent Trends", in Jane Lewis (ed.), Children, Changing Families and Welfare States, Cheltenham, Edward Elgar: 90-109.

Boyer Danielle et Sonia Renouard, 2004, Les hommes bénéficiaires de l'APE. Quels arbitrages au sein des couples, Dossier d'Etudes, CAF, juin 2004, 57: 1-51.

Brunet Florence, Pauline Kertudo et Sylvie Malsan, 2008, Étude sociologique sur la résidence en alternance des enfants de parents séparés, FORS Recherche Sociale, Dossier d'Etudes 109, Paris, CAF: $1-114$.

CABré Anna and Juan Antonio Módenes, 2004, "Home Ownership and Social Inequality in Spain", in Karin Kurz and Hans-Peter Blossfeld (eds.), Home Ownership and Social Inequality in Comparative Perspective, Stanford, Stanford University Press.

Cameron Claire and Peter Moss, 2007, Care Work in Europe: Current Understandings and Future Directions, Oxford, Routledge.

Chaussebourg, Laure, Valérie Carrasco et Aurélie LermeNIER, 2009, Le divorce, Paris, Ministère de la Justice, Sousdirection de la Statistique et des Études.

Chevalier Émilie, 2006, Les bénéficiaires du congé paternité, Dossier d'Études, 78, CAF: 1-121.

Commaille Jacques et Claude Martin, 1998, Les enjeux politiques de la famille, Paris, Bayard.

Deven Fred and Peter Moss (eds.), 1999, Parental Leave: Progress or Pitfall? Policy and Research Issues in Europe, The Hague/Brussels, NIDI/CBGS Publications.

Duvander Ann-Zofie and Ann-Christin Jans, 2008, "Consequences of Fathers' Parental Leave Use: Evidence from Sweden", Stockholm Research Reports in Demography, 2008: 9, Stockholm, Stockholm University.

EMERY Robert E., Randy K. OTtO and William T. O'DONOHUE, 2005, "A Critical Assessment of Child Custody Evaluations: Limited Science and a Flawed System", Psychological Science in the Public Interest, 6, 1: 1-29.

EPEC-COWI, forthcoming, Study on Paternity Leave in the EU 2011. European Commission.

Escobedo Anna, 2008, Leave Policies and Public Systems of Care for Children under Three Years Old and their Families in the European Union, doctoral dissertation, Universidad Autònoma de Barcelona.

Escobedo Anna, Lara Navarro and Lluís Flaquer, 2008, El impacto de la maternidad y la paternidad en el empleo. Análisis de cambios y discontinuidades a partir de la Muestra Continua de Vidas Laborales, research report, Madrid, FIPROS.
EUROPEAN COMMISSION, 2010, Indicators for Monitoring the Employment Guidelines Including Indicators for Additional Employment Analysis, Compendium.

FAGNANi Jeanne and Antoine Math, 2009, "France: Gender Equality a Pipe Dream?", in Sheila B. Kamerman and Peter Moss (eds.), The Politics of Parental Leave Policies: Children, Parenting, Gender and the Labour Market, London/New York, The Policy Press: 103-117.

Flaquer Lluís, 2008, "Coming in from the Cold: Single Parenthood as a Matter of Social Policy in Spain", in Ursula Von Der Leyen and Vladimir Spidla (eds.), European Alliance for Families, Portland, Nomos Publishers.

Flaquer Lluís and Anna Escobedo, 2009, “The Metamorphosis of Informal Work in Spain: Family Solidarity, Female Immigration and Development of Social Rights", in Birgit Pfau-Effinger, Lluís Flaquer and Per Jensen (eds.), Formal and Informal Work: the Hidden Work Regime in Europe, New York, Routledge: 143-168.

Flaquer Lluís and Anna Garriga, 2009, "Marital Disruption in Spain: Class Selectivity and Deterioration of Economic Conditions", in Hans-Jürgen Andreß and Dina Hummelsheim (eds.), When Marriage Ends: Economic and Social Consequences of Partnership Dissolution, Cheltenham, Edward Elgar: 178-210.

Flouri Eirini, 2005, Fathering and Child Outcomes, Chichester, John Wiley and Sons.

GRANET Frédérique, 2008, "Alternating Residence and Relocation: A View from France", Utrech Law Review, 4, 2: 48-54.

HaAtaja Anita, 2009, Fathers'Use of Paternity and Parental Leave in the Nordic Countries. The Social Insurance Institution of Finland, Helsinki, Online working papers, 2/2009.

Halla Martin, 2009, "The Effect of Joint Custody on Marriage and Divorce", IZA Discussion Paper 4314, Bonn, Forschungsinstitut zur Zukunft der Arbeit.

Hobson Barbara and David Morgan, 2002, "Introduction", in Barbara Hobson (ed.), Making Men into Fathers: Men, Masculinities and the Social Politics of Fatherhood, Cambridge, Cambridge University Press: 1-21.

Hunt Joan and Ceridwen Roberts, 2004, "Child Contact with Non-resident Parents", Family Policy Briefing 3, Department of Social Policy and Social Work, University of Oxford.

INE, 2010, "Estadística de nulidades, separaciones y divorcios. Año 2009", Notas de prensa (6 de septiembre de 2010), Madrid, Instituto Nacional de Estadística.

JuRAdO Teresa, 2001, Youth in Transition: Housing, Employment, Social Policies, and Families in France and Spain, Aldershot, Ashgate.

Kamerman Sheila B. and Peter Moss (eds.), 2009, The Politics of Parental Leave Policies: Children, Parenting, Gender and the Labour Market, London/New York, The Policy Press.

Kelly Joan B., 2007, “Children's Living Arrangements Following Separation and Divorce: Insights from Empirical and Clinical Research", Family Process, 46, 1: 35-52.

KestemAn Nadia, 2007, "La résidence alternée: Bref état des lieux des connaissances socio-juridiques ", Recherches et Prévisions, 89: 80-86.

KurkI-SuONIO Kirsti, 2000, "Joint Custody as an Interpretation of the Best Interests of the Child in Critical and 
Comparative Perspective", International Journal of Law, Policy and the Family, 14: 183-205.

Lammi-Taskula Johanna, 2006, "Nordic Men on Parental Leave: Can the Welfare State Change Gender Relations?", in Anne Lise Ellingsaeter and Arnaug Leira (eds.), Politicising Parenthood in Scandinavia: Gender Relations in Welfare States, Bristol, Polity Press: 79-100.

LAPUerta Irene, Pau BAizÁn and María José GonZÁlez, 2011, "Individual and Institutional Constraints: an Analysis of Parental Leave Use and Duration in Spain", Population Research and Policy Review, 30, 2: 185-210.

MEC, 2011, Las cifras de la Educación en España. Estadísticas e indicadores. Spanish Ministry of Education website.

Moss Peter, 2008, "Making Parental Leave Parental: an Overview of Policies to Increase Fathers' Use of Leave", in Peter Moss and Marta Korintus (eds.), International Review of Leave Policies and Related Research, Employment Relations Research Series, 100, UK Department for Business, Enterprise and Regulatory Reform.

Moss Peter and Jirina KocourkovÀ (eds.), 2010, International Review of Leave Policies and Related Research, Employment Relations Research Series, 115, Uk Department for Business, Innovation \& Skills.

Neyrand Gérard, 1994, L'enfant face à la séparation des parents. Une solution, la résidence alternée, Paris, Syros.

Nicolas Muriel, 2010, "Interrompre ou réduire son activité à la naissance d'un enfant et bénéficier du CLCA de la PAJE ", L'e-ssentiel, 97, CNAF: 1-4.
Nordic Council of Ministers, 1995, Towards New Masculinities - Report from a Nordic Conference on Men and Gender Equality, Copenhagen, Nord: 26.

O'Brien Margaret, 2009, "Fathers, Parental Leave Policies and Infant Quality of Life: International Perspectives and Policy Impact", The Annals of the American Academy of Political and Social Science, Special Issue: Fathering across Diversity and Adversity, 624, 1: 190-213.

O'Brien Margaret, Berit Brandth and Elin Kvande, 2007, "Fathers, Work and Family Life: Global Perspectives and New Insights", Community, Work and Family, 10: 375-386

RostgaArd Tine, 2002, "Setting Time Aside for the Father: Father's Leave in Scandinavia", Community, Work and Family, 5, 3: 343-364.

Ryrstedt Eva, 2003, "Joint Decisions - A Prerequisite or a Drawback in the Joint Parental Responsibility", Australian Journal of Family Law, 17: 1-53.

The Fatherhood Institute, 2010, The Fatherhood Report 2010-11. The Fairness in Families Index, Abergavenny, The Fatherhood Institute.

TRUC Gérôme, 2006, «La paternité en maternité: une étude par observation ", Ethnologie française, XXXVI, 2: 341-349.

Valiente Celia, 1997, "The Rejection of Authoritarian Policy Legacies: Family Policy in Spain (1975-1995)", MIRE Florence Conference, Comparing Social Welfare Systems in Southern Europe, Paris, MIRE, vol. III: 363-83.

Wall Karin and Anna Escobedo, 2009, "Portugal and Spain: Two Pathways in Southern Europe", in Sheila B. Kamerman and Peter Moss (eds.), The Politics of Parental Leave Policies: Children, Parenting, Gender and the Labour Market, London/New York, The Policy Press: 207-226.

\section{ABSTRACT}

The Social Politics of Fatherhood in Spain and France: A Comparative Analysis of Parental Leave and Shared Residence

The article provides a comparative analysis of policy developments on leaves for fathers and joint custody in Spain and France in the last decade. These two types of measures have been selected because they are both widely recognised as main instruments to promote new fathering styles and consequently more gender equality in the European Union. While the rhetoric of choice has been developed in both countries in relation to maternal employment and childcare, with better results in France than in Spain, it remains to be seen to what extent choice will also be extended to fathers.

Keywords: Fatherhood. Family. Comparative social policy. Parental leave. Joint custody.

\section{ZUSAMMENFASSUNG}

Sozialpolitik und Vaterschaft in Spanien und Frankreich: Eine vergleichende Analyse von Elternzeit und Zusammenleben

Die Entwicklung der französischen und spanischen Familienpolitik (Stichwort: Elternzeit oder gemeinsame Kinderbetreuung) der letzten zehn Jahre wird in diesem Artikel vergleichend analysiert. Beide Maßnahmen gelten als wichtige Instrumente der Verbreitung neuer Elternmodelle und in Konsequenz als Faktoren größerer Gleichheit zwischen Frauen und Männern in der Europäischen Union. Da sich die Familienpolitik in beiden Ländern vor allem an berufstätige Frauen richtet - derzeit mit größerem Erfolg in Frankreich als in Spanien - so bleibt vorerst noch abzuwarten welche Wahlmöglichkeit sich den Vätern erschließen wird. Stichworter: Vaterschaft. Familie. Vergleichende Sozialpolitik. Elternzeit. Gemeinsame Kinderbetreuung. 